\title{
Investigating the Essential Factors on Students Motivation through Comparing Boys and Girls in Terms of Instrumental \& Integrative Motivation in EFL Classrooms
}

\section{Lokman Coskun}

\author{
A lecturer at Beder University, a PhD candidate in European of University, \\ Department of Education Sciences, Tirana, Albania \\ Mail-1: Iokmancoskun@hotmail.com, Mail-2: Icoskun@beder.edu.al
}

\section{Doi:10.5901/jesr.2014.v4n2p150}

\begin{abstract}
The aim of this study is to identify and examine Albanian's private secondary school students' instrumental motivation towards learning English as a second language. Instrumental motivation was considered inclusively, but integrative motivation in general terms. The present study employs a quantitative approach in relation with collecting data by a survey which has questionnaire aiming to measure the motivational factors on the students in single-sex environment and its useful outcomes regarding English language teaching. The questionnaire was developed by Glynn, S. M., \& Koballa, T., R., Jr. (2006) and adapted from it. As the demographic information, just gender was requested in the questionnaire. In this study, the questionnaire was utilized in two different selected single-sex secondary private schools separately (girls and boys) in Albania to identify motivation for learning English. A 31-item survey was done based on classroom-administration to find out interest and inclination of the students towards learning English and to clarify how they were motivated instrumentally.
\end{abstract}

Keywords: Motivation, Private School, Single Sex Education, Environment, Lingua Franca, Command, Demand, Single-Sex, Coeducation

\section{Introduction}

Motivation affects students' performance in language learning environment. This present study deals with instrumental motivation and the gender in English language learning process. The findings will be discussed and views will be put forward.

Albania increases its relations with other countries, and the importance of an international language such as English appears essential for improving those relations with the world. Actually, an international language is called a lingua franca. As lingua franca, English language learning becomes a must for international relations. That's why, many people wanted to learn this language, and motivation of the learners started to play an important role not only in Albania but also in the world too.

Motivation might be instrumental and integrative, and necessary in teaching environment where the latest demands in relation with learning English language augmented and also private schools try to meet the demands for learning that language. Increasing the motivation of the learners is needed to make learning process easy. Otherwise, this learning process is likely to be challenging for teachers.

In this study, quantitative method was used for collecting data. Besides, questionnaire methodology was regarded for comparison of single-sex schools to collect data. Single-sex teaching environment seems more productive in language teaching. The latest demands regarding learning English is analyzed in private school environment in relation with motivational factors that require better learning for better command of English. Therein, gender difference was considered and integrative and instrumental motivation was compared in EFL environment.

Evidences demonstrate that single sex schools have fruifful impact for motivation of the students. The gender is considered differently through taking into account the learning environment. In fact, motivation is an abstract issue. Dörnyei, Z. (2001, p:1) states that "motivation is an abstract, hypothetical concept that we use to explain why people think, behave as they do."

This study suggests that for long term academic achievements, single sex schools should be established. Because, single sex schools are expected and demanded from existing parents to meet the demands for learning this lingua franca. As a result, instrumental approaches motivate learners' more than integrative motivation. 


\section{Literature Review}

The existing literature enables necessary data for this research. Regarding motivation, Muhammad, A,. et. al., (2013), states that "The most effective way to get insight into the learning process is to study the learners' attitude and motivation towards learning English language." Besides, Mehmet N. G. (2001), says "learning can only happen if certain affective conditions, such as positive attitudes, self-confidence, low anxiety, exist and that when these conditions are present input can pass through the affective filter and be used by the learner."

Instrumental and integrative motivations explain this study effectively. Actually, teachers need to find ways to motivate their respective students. Mehmet N. G. (2001), expresses that "Motivation depends on the social interaction between the teacher and the learner." and says more about it such as; "The success of a teacher in second language acquisition in school affects directly the success of learners."

On the other hand, Mehmet N. G. (2001) expresses that "The choice of teaching strategy has an effect upon the motivation and interest of the student. The manner in which the teacher approaches the teaching strategy will have an effect upon motivation: an enthusiastic approach is more likely to motivate than a dull approach."

Cavallo, Rozman, Blinkenstaff, \& Walker, (2003) says that "Achievement motivation is students' motivation toward performance goals (such as earning high grades, getting praise, or performing better than other students) or toward learning goals (such as learning something new, learning for the sake of learning, or improving oneself)." Mehmet N. G. (2001), says that "Achieving motivation lets the learner a desire to learn a language."

Glynn, S.M., et, al., (2007) states that the female learners are "more likely to attend class on time, sit in the front of the class, take notes, study the textbook, and study in an organized way-all behaviors associated with a relatively high motivation to learn." More than that, Muhammad, A,. et. al., (2013), expresses that "girls' tend to demonstrate significantly more positive attitudes than boys do, recognizing also that they are more successful in learning languages than boys."

According to Glynn, S.M., et, al., (2007), the "motivation to learn is "a student's tendency to find academic activities meaningful and worthwhile and to try to derive the intended academic benefits from them."

This present study suggests instrumental motivation while teaching/learning language. Muhammad, A,. et. al., (2013), says more and states that "Gender is supposed to have an important effect on attitude and motivation and learning process."

\section{Discussion}

In international relations for better communications and also in academic careers, English Language as Lingua Franca plays a considerably important role at home and abroad. Additionally, the motivation of learning this language deserves attention as well, for it contributes too much to the nation's economy.

This study demonstrated that Albanian students were motivated towards learning English instrumentally. Especially, girls showed high level motivation when compared to boys. On the other hand, instrumental motivation might help them reach their academic goals and students' participation in the study in private schools appears instrumentally due to practical value of English Language and learning English is relevant to their life as well.

Today, Albania tries to organize various international conferences, of course; a Lingua Franca is needed to communicate and establish relations with the other world. But, because of side effects of communism people could not learn English and also limited numbers of English speaking people as tourists are visiting Albania. Then, Albanian people cannot have opportunities to get in touch with tourists to improve their English. If English is spoken by large number of people here, activities and contacts with other countries will increase in this country. Hence, private schools play a significant role in terms of language teaching. Thus, the contribution and benefit of private schools is apparent.

Albanian students have a better realization of English Language as Lingua Franca, and its opportunities. When students make future plan, English becomes their consideration and it is regarded as international standard for future plan. Lingua Franca is essential for going abroad to acquire international education. For that reason, students opt for English medium school or English medium universities to realize their ambitions, but those educational institutions are limited.

Further, student exchange programs and graduating from foreign universities are considered prestigious and encourage students to improve the English Language. That's why; students' approaches for learning English Language are instrumental in Albania. If the teachers help the learners how to improve this Lingua Franca and make them see the benefits of this language, then the students will enhance their language proficiency due to practical value of English 
Language and for their academic achievements. Therefore, both males and females have substantially stronger instrumental reasons for learning English that enables them academic achievements, future jobs and travel abroad.

Research Questions:

- Single-sex schools have positive effects on students for long-term academic achievements.

- Albanian students are motivated more instrumentally than integratively towards learning English.

\section{Research Methodology}

235 non-English students out of both girls and boys were selected to complete a questionnaire to find out factors of their motivation for learning English. Two prestigious private school of Albania were sampled. Qualitative and quantitative data were used to assess and evaluate students' performances in relation with language learning motivation. As methodology, survey research was used. A classroom-administered survey was regarded to obtain easy, simple, efficient, and productive outcomes. The participants were assured of their anonymity and brief information was given about the research. The data regarding the study were then obtained through different statistical analyses.

Primary and secondary data were considered to assess and evaluate the Albanian private educational environment in secondary private school. A 31-item survey questionnaire was used for students to evaluate the motivation of the students towards English Language Learning in private school education instrumentally, before now, the questionnaire was developed by Glynn, S. M., \& Koballa, T., R., Jr. (2006) and adapted from it. As the demographic information, just gender was requested in the questionnaire.

A self-completion questionnaire of this study was handed over and answered by the respondents. SBSS statistics 21 version was used to obtain data, just only 120 were considered as valid and reliable.

\section{Limitation and Significance of Study}

Instrumental motivation scale was mainly designed to identify students' motivation instrumentally, in case of single-sex education and to know which sex was more motivated than the others while learning English Language, when compared to boys and girls.

While conducting the pilot studies in secondary schools, two main constraints were faced; firstly, the study was conducted at the end of second semester in May when many school exams and public exams were held. Secondly, the study was targeted to be done among more than 300 hundred students to ensure validity and reliability of it.

The study was conducted among a group of 240 male and female secondary school students who are mostly successful language learners with inclusion of some moderately language learners. However, the results obtained from the study showed reliable findings. In the pilot study, the participation of more successful language learners helped to ensure reliability and validity of the study.

\section{Findings}

Instrumental Motivation Scale (IMS) was successfully piloted with plausibly good results of reliability and factor analysis; various issues regarding motivation were identified to be discussed in this section.

As the present study aimed to examine the gender differences of the participants concerning attitudes and motivation toward learning English, the researcher has analyzed the data through SPSS (version 21). As factors, attitude and motivation have been used as dependent variables and gender was as independent variable. All statistical data were to investigate the gender differences and motivational factors in terms of learning language. 


\subsection{Frequency-1}

Table -1-A

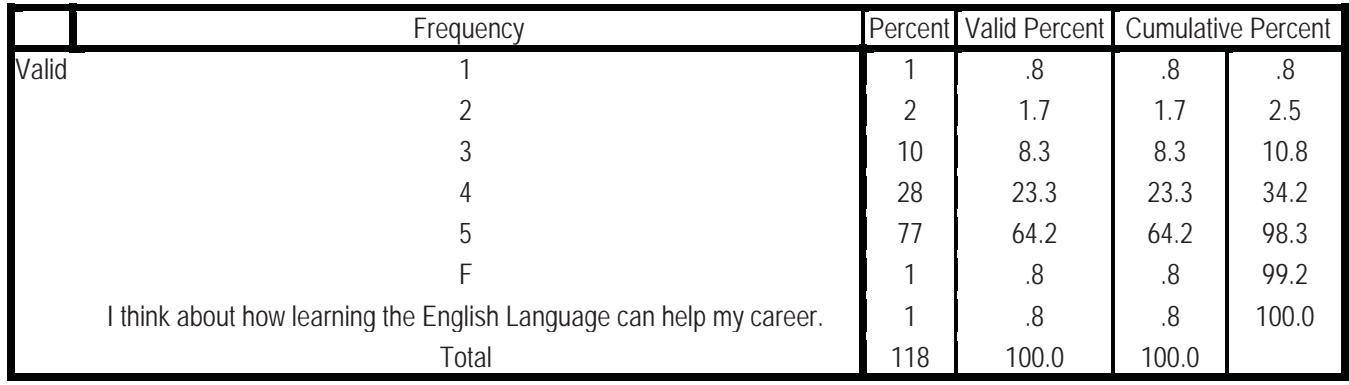

Table -1-B

\begin{tabular}{|c|c|c|c|c|c|}
\hline \multirow{2}{*}{ Valid } & \multirow[t]{2}{*}{ Frequency } & \multirow{2}{*}{ Percent } & \multirow{2}{*}{$\begin{array}{c}\text { Valid Percent } \\
.8\end{array}$} & \multicolumn{2}{|c|}{ Cumulative Percent } \\
\hline & & & & .8 & .8 \\
\hline & 1 & 1 & .8 & .8 & 1.7 \\
\hline & 2 & 2 & 1.7 & 1.7 & 3.3 \\
\hline & 3 & 15 & 12.5 & 12.5 & 15.8 \\
\hline & 4 & 44 & 36.7 & 36.7 & 52.5 \\
\hline & 5 & 55 & 45.8 & 45.8 & 98.3 \\
\hline & I think about how learning the English Language can help my career. & 1 & .8 & .8 & 99.2 \\
\hline & M & 1 & .8 & .8 & 100.0 \\
\hline & Total & 117 & 100.0 & 100.0 & \\
\hline
\end{tabular}

\subsection{Frequency-2}

Table -2-A

\begin{tabular}{|c|c|c|c|c|c|}
\hline & Frequency & Percent & Valid Percent & \multicolumn{2}{|c|}{ Cumulative Percent } \\
\hline \multirow[t]{8}{*}{ Valid } & 1 & 2 & 1.7 & 1.7 & 1.7 \\
\hline & 2 & 5 & 4.2 & 4.2 & 5.8 \\
\hline & 3 & 18 & 15.0 & 15.0 & 20.8 \\
\hline & 4 & 36 & 30.0 & 30.0 & 50.8 \\
\hline & 5 & 57 & 47.5 & 47.5 & 98.3 \\
\hline & $\mathrm{F}$ & 1 & .8 & .8 & 99.2 \\
\hline & The English Language I learn is relevant to my life. & 1 & .8 & .8 & 100.0 \\
\hline & Total & 118 & 100.0 & 100.0 & \\
\hline
\end{tabular}

Table -2-B

\begin{tabular}{|c|c|c|c|c|c|}
\hline & Frequency & Percent & Valid Percent & \multicolumn{2}{|c|}{ Cumulative Percent } \\
\hline \multirow{9}{*}{ Valid } & & 1 & .8 & .8 & .8 \\
\hline & 1 & 1 & .8 & .8 & 1.7 \\
\hline & 2 & 6 & 5.0 & 5.0 & 6.7 \\
\hline & 3 & 30 & 25.0 & 25.0 & 31.7 \\
\hline & 4 & 40 & 33.3 & 33.3 & 65.0 \\
\hline & 5 & 40 & 33.3 & 33.3 & 98.3 \\
\hline & M & 1 & .8 & .8 & 99.2 \\
\hline & The English Language I learn is relevant to my life. & 1 & .8 & .8 & 100.0 \\
\hline & Total & 117 & 100.0 & 100.0 & \\
\hline
\end{tabular}


In relation with frequency data determined, and as in Table-1-A and Table-1-B, and also in Table-1-A and Table-1-B concerning "instrumental motivation". The frequency data is 77 and 57 for the female students who state that "I think about how learning the English Language can help my career". And also the statement such as "The English Language I learn is relevant to my life". In case, it is compared to male students, the frequency appears as 55 and 40 . It is clear to say that female students are motivated more instrumentally than boys in Language learning.

\subsection{Frequency-3}

Table -3-A

\begin{tabular}{|c|c|c|c|c|c|}
\hline & Frequency & Percent & Valid Percent & \multicolumn{2}{|c|}{ Cumulative Percent } \\
\hline \multirow[t]{8}{*}{ Valid } & 1 & 2 & 1.7 & 1.7 & 1.7 \\
\hline & 2 & 3 & 2.5 & 2.5 & 4.2 \\
\hline & 3 & 18 & 15.0 & 15.0 & 19.2 \\
\hline & 4 & 45 & 37.5 & 37.5 & 56.7 \\
\hline & 5 & 50 & 41.7 & 41.7 & 98.3 \\
\hline & $\mathrm{F}$ & 1 & .8 & .8 & 99.2 \\
\hline & I put enough effort into learning the English Language. & 1 & .8 & .8 & 100.0 \\
\hline & Total & 118 & 100.0 & 100.0 & \\
\hline
\end{tabular}

Table -3-b

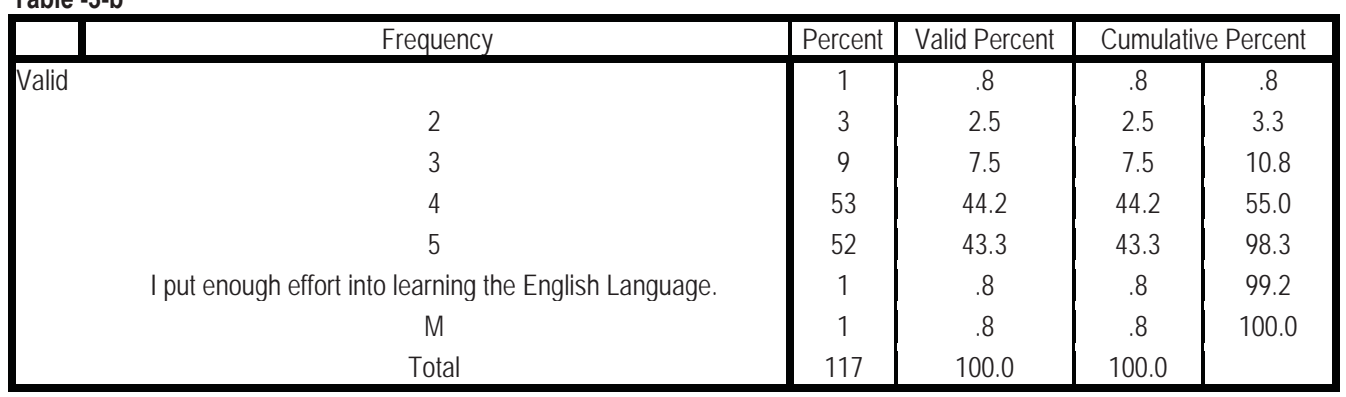

\subsection{Frequency-4}

Table -4-A

\begin{tabular}{|c|c|c|c|c|c|}
\hline & Frequency & Percent & Valid Percent & \multicolumn{2}{|c|}{ Cumulative Percent } \\
\hline Valid & 1 & 37 & 30.8 & 30.8 & 30.8 \\
& 2 & 41 & 34.2 & 34.2 & 65.0 \\
& 3 & 25 & 20.8 & 20.8 & 85.8 \\
& 4 & 9 & 7.5 & 7.5 & 93.3 \\
& 5 & 6 & 5.0 & 5.0 & 98.3 \\
& $F$ & 1 & .8 & .8 & 99.2 \\
I am concerned that the other students are better in English Language. & 1 & .8 & .8 & 100.0 \\
& Total & 118 & 100.0 & 100.0 & \\
\hline
\end{tabular}




\begin{tabular}{|c|c|c|c|c|c|}
\hline & Frequency & Percent & Valid Percent & \multicolumn{2}{|c|}{ Cumulative Percent } \\
\hline \multirow[t]{9}{*}{ Valid } & & 1 & .8 & .8 & .8 \\
\hline & 1 & 35 & 29.2 & 29.2 & 30.0 \\
\hline & 2 & 35 & 29.2 & 29.2 & 59.2 \\
\hline & 3 & 33 & 27.5 & 27.5 & 86.7 \\
\hline & 4 & 10 & 8.3 & 8.3 & 95.0 \\
\hline & 5 & 4 & 3.3 & 3.3 & 98.3 \\
\hline & I am concerned that the other students are better in English Language. & 1 & .8 & .8 & 99.2 \\
\hline & M & 1 & .8 & .8 & 100.0 \\
\hline & Total & 117 & 100.0 & 100.0 & \\
\hline
\end{tabular}

As it is clearly understood in frequency data determined as Table 3-A and Table 3-B, and Table 4-A and Table 4-B regarding "integrative motivation", the frequency value appears as 50 and 6 for female students who express that "I put enough effort into learning the English Language". And also in the statements such as, "I am concerned that the other students are better in English Language". But, the frequency for male students is seen as 52 and 4. In case, it is compared to female students. According to these findings, we can say that Albanian students are not motivated interactively.

The responses from obtained data show that many students were motivated to learn English Language, not only it is relevant to their careers, but also they consider it relevant to understand the world.

Mael et. al., (2005) emphasizes that single-sex education imparts more positive outcomes in terms of academic achievement, and for longer-term outcomes, the achievement is not easily obvious and also adds that this type of education results in future academic achievements such as career aspirations for girls.

Besides, Mael et. al., (2005) says that single-sex education draws more attention of the students to academic interest than in socializing, and adds that this education places more importance on grades \& leadership, but less importance on money and attractiveness in relation with both males and females.

\section{Conclusion}

The findings show that Albanian students learn English due to instrumental motivation, such as; practical reasons for personal achievements, present value of Lingua Franca and providing better future career for students. Mehmet N. G. (2001) says that "Studies on motivation show that motivated learners are more successful in second language acquisition."

The recent demands for learning English language in the private school classroom environment in secondary school enable motivations to be analyzed. The finding indicates that co-education is not a good option for motivation of the students in language learning and for other academic achievement. It suggests that there should be a separate learning environment in terms of gender difference to motivate students for better language command.

The study recommends that various research activities to be conducted concerning the evaluation of students' motivation instrumentally, while preparing language teaching/learning curriculum with the aid of effective motivation strategies. The finding shows that Albanian students are motivated in an effective and viable way with the aid of instrumental motivational approach.

So far, there is no a supernatural method for motivating language learners, whereas some motivational strategies might be appropriate to learners and those strategies can affect language learners positively. Besides, the abstractness of motivation makes it difficult for teachers, but, critical approaches in relation with learners' motivational models are necessary for the course of an academic program.

\section{References}

Cavallo, A.M.L., Rozman, M., Blinkenstaff, J., \& Walker, N. (2003). Students' learningapproaches, reasoning abilities, motivational goals, and epistemological beliefs in differing college science courses. Journal of College Science Teaching, 33, 18-23.

Dörnyei, Z. (2001). Motivational strategies in the language classroom. Cambridge: Cambridge University Press. Retrieved on, 14/10/2013 http://lib.free-college.org/view.php?id=560972

Glynn, S.M., Taasoobshirazi, G., \& Brickman, P. (2007). Nonscience majors learning science: A theoretical model of motivation. Journal 
of Research in Science Teaching, 44, 1088-1107.

Glynn, S. M., \& Koballa, T., R., Jr. (2006). Motivation to learn college science. In J. J. Mintzes \& W. H. Leonard (Eds.), Handbook of college science teaching (pp. 25-32). Arlington, VA: National Sience Teacher Association Press. Retrieved on: 11/12/2013, from: http://www.coe.uga.edu/smq/files/2011/10/10-Glynn-Koballa-2006.pdf

Kim, S. (2011). Is Motivation Changeable? : Exploring the Possibility and Principle of Public Service Motivation Change. Korea University. Retrieved on, 14/10/2013 http://ajou.ac.kr/ seoyong/paper/ls\%20Motivation\%20ChangeableWith\%20Cheouljo\%20Lee.pdf

Mael f., A. Alonso, D. Gibson, K. Rogers, and M. Smith. (2005). "Single-sex Versus Coeducational Schooling: A systematic review." Washington, DC: US Department of Education. Retrieved: 19/06/2013

Mehmet Nuri Gömleksiz. (2001). The Effects Of Age And Motivation Factors On Second Language Acquisition.Frrat University Journal of Social Science. Vol: 11 Number: 2, Page: 217-224, Elaziğ-2001.

Muhammad, A. and Mamuna G. (2013). Gender and Language Learning Motivation. Academic Research International, Vol. 4 No. 2 March 2013.

Ng, K.T., Soon, S.T. \& Fong, S.F. (2010). Development of a Questionnaire to Evaluate Students' Perceived Motivation towards Science Learning Incorporating ICT Tool. Malaysian Journal of Educational Technology, 10(1), pp. 39-55.

Zolt'n Dörnyei (1998). Motivation in second and foreign language learning. Language Teaching, 31, pp 117-135

Vaezi, Z., (2008). "Language Learning Motivation among Iranian Undergraduate Students." World Applied Sciences Journal, 5(1): 54-61. 